\title{
Important Motivators for Buying Green Products
}

\author{
Kamyar Kianpour, Roya Anvari*, Ahmad Jusoh, Muhammed Fauzi Othman \\ Faculty of Management, Universiti Teknologi Malaysia (UTM), (Malaysia) \\ kamyar_wkf@yahoo.com,*Corresponding author roya.anvari@utm.my, \\ ahmadj@fppsm.utm.my,m-fauzi@utm.my
}

Received September, 2013

Accepted October, 2014

\section{Abstract}

Purpose: To addresses the main motivators that influence customers to buy green products as well as well as profiling the decisions that shape their behavior.

Design/methodology/approach: The authors have conducted a review of the major research related to consumers to identify motivational factors, to draw conclusions about their impact on buying green products. Factor analysis is conducted on the collected data to find the underlying factors that motivate consumers to buy green products and most importantly motivational factors were identified by $\mathrm{T}$ test.

Findings: Results show that 1) Environmental Concern, Perceived Consumer Effectiveness, Consumer Knowledge 2) Laws and regulation and 3) Promotional Tools' were the most important of motivators.

Practical implications: The results could help companies, authorities, governments, producers, sellers to know what motivate customers to buy green products and persuade the customers for buying them.

Social implications: Furthermore this research will indirectly contribute to increase the customers and public intention for buying green products which in turn will help to solve some of environmental issues and make less environmental side effect caused by products. It is notable that motivated consumers for buying green product will finally 
expect to have healthy life and clean environment which leads to a healthy and clean society.

Originality/value: This article contributes to the literature on the customers' intention for buying green products by filling the gap in the concrete issues of the customers' motivation.

Keywords: Consumers' Buying Behavior, Green Purchasing motivators, Environmentally friendly products

Jel Codes: M31

\section{Introduction}

In the past production has been the focus without adequate focus on the awareness about adverse environmental effects. Respectively, people have produced many different types of technology and products. They still are exploring new technologies to produce new tools and products to make life easy for human. People always buy the products best satisfy them with a high quality as well as value to themselves; however they seldom think to buy products with minimum side effect for protecting the nature and environment.

Environmental problems such as: climate change, soil and water pollution and other catastrophic issues were repeatedly raised up in current decade thus making governments, organization and people more concern and try to participate in solving environmental problems. They have become more concerned with the natural environment and are realizing that their production, consumption and purchasing behavior will have a direct impact on the environment (Laroche, Bergeron \& Barbaro-Forleo, 2001). This awareness is in apparent with the belief that the world's supply of natural resources is finite and the ecological balance of the environment may be at a critical disruption stage (Hayes, 1990).

The companies try to produce the eco-friendly products to serve customers' needs and satisfaction. Therefore it is necessary for the organization to understand customer attitude and be vary of their behavior which include motivation that the consumer in buying green product.

Studies have shown that human needs are the basis for any movement. Abraham Maslow purported this in his theory of motivation. Therefore, whenever the customers feel that they should buy Environmentally friendly products, they would automatically purchase them (Maslow, 1943). So it is important to understand which factors motivate customers to buy a product which is environmentally friendly. For that a reason, it is necessary to examine different motivators related to normal products and to the green products. The research 
question for this research is: what are the motivators of buying environmentally friendly products among consumers? Based on the research question two objective is formulated which is: to examine the motivators that would persuade a customer for choosing environmentally friendly product as compared to other products.

Discussion showed the importance of customer and consumer behavior for buying green products but there is a gap about what motivates the people to buy green products thus it is not discussed comprehensively or there are just a few research papers produced in this filed.

Three objectives were been designed as follows:

- To investigate the common important motivators for buying the green products from synthesis literature.

- To build a valid construct based on the literature review of other researchers about common motivators for buying green products.

- To identify which one of these motivators which are more important based on from the responses.

This paper is organized in the following order:

- Literature review which consists of buying behavior, Green buying behavior and motivators for buying green products.

- Part two discusses the research methodology,

- part three is identification of green purchasing motivators' constructs using factor analysis,

- part four is about reliability and validity test;

- the part five represents the results,

- part six is about discussion and conclusion and

- in the final part authors will discuss about contributions, considerations, limitations and future Work.

\section{Literature Review and Hypotheses}

Since this paper aims to investigate the motivators of buying green products, it is appropriate to review the literature on buying behavior and accordingly green buying behavior as a starting point. Subsequently the motivators of purchasing green products have been discussed in the last part of literature review. 


\subsection{Buying Behavior}

As the buying behavior is an older concept and the basis for green buying behavior, hence this part is a quick review of different studies in the field of consumer behavior and buying behavior as well. This review will help to understand the definition, context and main elements of buying behavior investigated by different authors. Engel, Blackwell and Miniard (2005) defined the consumer behavior as "those activities directly involved in obtaining, consuming, and disposing of products and services, including the decision processes that precede and follow these activities". Schiffman and Kanuk (2007) argued that consumer behavior is "the behavior that consumers display in searching for purchasing, using, evaluating and disposing of product, service and idea which they expect, will satisfy their requirements". Sandhusens' Black Box model (2000) defines the consumer behavior's main elements and shows the interaction of Environmental Factors (including marketing stimuli (MIX) and environmental stimuli), Buyer's Black Box (including Buyers Characteristics and decision process) and finally Buyer's Response.

Therefore, knowing the factors those influence the buying behavior could increase the sales volume. Kacen and Lee (2002) claimed that both level factors (individualism-collectivism) and individual cultural difference factors (independent -interdependent self-concept) systematically influence impulsive purchasing behavior. Kotler stated that Consumer buyer behavior includes the buying behavior of final consumers-individuals and households that buy goods and services for personal consumption. All of these final consumers contribute to make up the consumer market. They also claimed that cultural, social, personal and psychological factors influence buyer's behavior.

In another study, different factors that motivates buyers to purchase products were discussed studied by Talluri (2002) those are mainly: Personal Factors, Situational factors, The Reason for the Consumer's Purchase and Societal Factors.

Reviewing the literature related to consumer and buying behavior has helped us have a better understanding of green buying behavior and finding the main motivators affecting the purchasing of green products.

\subsection{Green Buying Behavior}

After defining the buying behavior, one more subject comes to the content which is green buying behavior. Hallin (1995) as well as McCarty and Shrum (2001), regarded it as people engaging in environmental behavior as a result of their desire to solve environmental problem, to become role models and a belief that they can help to preserve the environment. However, 
consumers' indications of positive attitude towards environmental issues do not necessarily lead to actual environmentally friendly purchasing behavior (Laroche et al., 2001). Majority of consumers do not purchase products based on the environmental concern alone and they will not trade-off other product attributes for a better environment (Yam-Tang \& Chan, 1998).

There is considerable evidence that most western markets have been influenced by green consumer behavior, which means behavior reflects concern about the effects of manufacturing and consumption on the natural environment. Besides legal changes, over the past decade many companies began to feel the impact of market forces, such as changing buying habits, environmentally oriented costumer and boycotting behavior that resulted from media reporting and pressure group activity. Hueber (1991) stated that over 70 percent of Americans, for example, reported that they were in support of environmental protection, and 49 percent said that they would avoid purchasing products that are potentially harmful to the environment. Survey of environmentally oriented consumer behavior indicates that the number of consumers who include environmentally oriented consideration in their buying decision has been comparatively stable. Around 10 percent of British consumers expressed they have integrated environmental issues very consistently in their buying behavior. Other markets like USA, Canada, Germany, Netherlands or the Scandinavian countries, shows that green consumer behavior is hotly debated. Green product options have stayed on the shelves of many retailers, which indicates that green consumers have remained a niche market that is worth for (Wagner, 1997).

Laroche et al. (2001) had a complete review of the relevant literature on several factors that might influence consumers' willingness to pay more for environmentally friendly products. The research classified the factors into five categories: demographics (age, gender, income, level of education, employment status and etc.), knowledge (eco-literacy), values (individualism, collectivism, security and enjoyment), attitudes (e.g., importance of being environmentally friendly) and behavior (e.g., considering environmental issues when purchasing) and provides a theoretical framework.

According to Boztepe (2012), environmental awareness, green product features, green promotion activities and green price could impact green purchasing behaviors of the consumers in a positive way, furthermore demographic characteristics have moderated the effect on the model.

Yeonshin and Sejung (2005) indicated that the impact of collectivism stream through PCE; the collectivistic value orientations effect beliefs regarding consumer effectiveness, which in turn impacts green buying behavior. Environmental concern, instead, directly affects green purchase behavior. 
Reviewing the literature on green purchasing or green buying behavior mainly help to understand the importance of green buying behavior and what have been done by different researchers in this field. In addition it would be easier to understand the main motivators impact consumers' behavior for buying green products.

\subsection{Motivators and Factors Which Motivate Customers}

To be motivated means to be moved to do something. An individual who has no feeling to perform any action is thus considered as unmotivated, while somebody who has been energized or triggered in the direction of an action is considered motivated. Many theories of motivation reflect these anxieties by observing motivation as a unitary phenomenon (Majlath, 2010). Here are several motivators and factors which are proposed by different authors that can affect customers' buying and purchasing attitude and willingness. These different surveys have been related to motivators and factors that impact buyers' willingness to buy normal products and green products. They are categorized to the following six different parts.

\subsubsection{Customers Concern for Buying Environmentally Friendly Products}

Clients, who are concern in environment, will buy green goods. Laroche et al. (2001) mentioned that "Concerns related to the environment are evident in the increasingly environmentally conscious marketplace. Recently, a majority of consumers have aware that their purchasing behavior directly impact on the ecology. Customers responded toward this threatening situation by considering environmental issues when shopping (e.g. checking if the product is wrapped in a recycled material) and by purchasing only ecology compatible products (e.g. biodegradable paint, CFC-free hairspray or unbleached coffee filters)" (Bergeron, Laroche, \& Barbaro Forleo, 2001). Consumers now take into consideration over the environment when they want to buy products. Environmental concern is a general approach that shows the level of consumer's anxiety about threats for the harmony of nature and the absence of human action for caring the environment for forthcoming generations (Bohlen, Schlegelmilch \& Diamantopoulos, 1993). Probably, people's level of environmental concern is connected to their attention and willingness for buying the green products. Earlier experimental evidence indicated that environmental concern is playing a significant role on consumer decision making (Zimmer, Stafford \& Stafford, 1994). Moreover, other studies examined connections between environmental concern (i.e. attitude) and environmentally friendly behavior (Roberts \& Bacon, 1997). However, Hume (1991) has a different finding on the connection between the positive attitude of consumers on the environment and their purchasing decision. He concluded that 
consumers do not always act in accordance with their social reporting about the environment and mentioned that "What people think is good idea, does not forecast what they actually do, especially in the case of environmental values and behaviors." On the other hand, an ecological opinion survey of the Canadian population and phone study of 387 of municipal Atlanta inhabitants both showed that peoples' level of environmentally friendly is related to their attention in willingness to acquisition of green products (Darnall, 2003). Based on above discussion, hypothesis 1 has been proposed for the study. Grant and Berry (2011) mentioned that prosocial motivation, which is the desire to protect and promote the well-being of others, can lead to develop ideas that are useful as well as novel. By this definition if the consumers are concern about the environment and well-being of society, this concern can motivate them to protect the environment by finding innovative ways and taking the right actions.

H1: Consumer's environmental concern is a motivating factor in purchasing green products.

\subsubsection{Reference Group}

Customers who have been influenced by specific group will purchase green products. One of the important motivators of environmentally responsible conduct is the social norms. Hoyer and MacInnis (2007) mentioned: "the strength of normative influence of the consumers' family and social groups on purchasing decision making depends on the characteristics of the product (e.g. luxury rather than a necessary, publicly displayed or used in private), the susceptibility of the individual consumer and the coercive power of the group to which the consumer belongs to". A reference group defines a group whose values and attitudes are used by an individual as a foundation for his or her current behavior (Schiffman \& Kanuk, 2007). Researchers and marketers are interested to work on normative reference groups and comparative reference groups, parents, co-workers, teachers, and peers who provide the individual with norms, values, and attitudes through direct interaction which are parts of normative reference groups (Rao \& Childers, 1992). Comparative reference groups have been defined as sports heroes and entertainment figures that provide standards. These reference groups are used in advertisement frequently, however they are related to the green products rarely (Charter, Peattie, Ottman \& Polonsky, 2002). The hypothesis proposed for this section is:

H2: Reference group is a motivating factor for buying environmentally friendly products. 


\subsubsection{Environmental Laws and Regulations}

Environmental problems have been raised in recent years by the governments and authorities who have become more concerned about environment. Hence they have ratified a big variety of rules and regulation for protecting the environmental as well as health and human safety. These rules and regulations basically can influence the consumers to use environmentally friendly products and companies to produce green products and service. Recently companies which are more influenced by the environment and standards such as the US, Environmental Protection Agency, Environmental policy of the European Union as are producing more environmental friendly products. Furthermore Clients who have been influenced by environmental rules and regulation also are more interested to buy green products. Environmental Laws and Regulations for the past 20 years have been implemented throughout the world to tackle the issue of "global warming". The pollutants implicated in the climate change models are produced by every country and virtually every sector of modern economies (Driesen, 2007). In a study conducted using the Portuguese as the respondents results show that consumers who buy green products do so for specific reasons, and that certain environmental and demographic variables are significant in differentiating between the 'greener' segment and other segments. Yet, generally speaking, one is left with the impression that the Portuguese sample, despite their support for policies designed to improve the environment, do not translate their idea into actions: they rarely join environmentalist associations and they do not take part in policy-making. Their participation is often based on protecting the environment by saving electricity and water, which shows that these concerns may be more closely related with economic factors than with an environmental consciousness (Paço \& Raposo, 2009). So the hypothesis for this part considered as:

H3: Environmental laws and regulation is a motivating factor for buying environmentally friendly products.

\subsubsection{Promotional Tools}

Customers who have been exposed to promotional tools will buy green products. Promotion is a powerful marketing communication tool. It is aimed to notify rather than just impress because communicating about environmental issues is difficult for marketers and involves complex issues without simple solutions, and messages which are difficult to reduce down to fit onto label, or into a 30 second TV commercial (Prothero, Turner \& Stoneman, 1997).

Advertising sustainable product has been used to grab customer's attention toward sustainable products, services and actions. It is not focus to environmental issues and products or service, but includes communication about the entire life cycle of the product. Besides, it provides 
information about the sustainability of the producing company and communicates desirable lifestyles changes to consumers (Belz \& Peattie, 2009).

Diana L Haytko and Erika Matulichin a research defined that, consumers who are more preemptive with their environmental behaviors, have better attitudes toward green advertising. They also mentioned that based on their investigations green advertising may be best at reaching those who are already involved in green behaviors.

Researchers also discussed about motivations for a firm to produce green advertising (Davis, 1992; Frankel, 1992; Gillespie, 1992; Ottman, 1992, 1998; Zinkhan \& Les, 1995). There are some researchers those investigated the consumer responses to green advertising and goods in terms of loyalty (Frankel, 1992), willingness to pay higher prices (Phillips, 1999; Schlossberg, 1992), and perceptions of product safety or harm to the environment (Davis, 1994; Wheeler, 1992).

Product endorsements occur when the environmental group endorses a product after it has been ensured that the product meets some set of established criteria. There are many private endorsement schemes operating around the world, though none of these appeared to receive the recognition they may deserve, nor they have been extensively utilized by the industry. These firms went on to promote themselves as being environmentally responsible because they did not use drift nets (Mendleson \& Polonsky, 1994).

The forth hypothesis for this research is:

Hypothesis 4: Promotional tools are motivating factors for buying green products.

\subsubsection{Consumer Knowledge}

Customers with awareness and knowledge of the environmental issues and problems will buy green products. Laroche et al. (2001) mentioned that involvement with a product and environmental issues are important constructs when assessing consumers' willingness to purchase. Previous research emphasized on the importance of the relationship between product involvement and product knowledge. Knowledge was found to be significantly related to how consumers gather, organize, and evaluate products, as well as being a significant predictor of environmentally friendly behavior. Perceived knowledge appears to contribute to perceived consumer effectiveness. Not surprisingly then, the greater people perceive their knowledge about buying recycled content products, the more likely they are to do so (Weiner \& Cobb, 1991). 
A key element of the environmental consciousness of consumption is the desire by consumers for more information about the relationship between products and environment, with greater exposure to 'green' information sources influencing consumer purchasing decisions. According to a study by GFK(Society for Consumer Research)(2007), "Americans have shifted to a more environmentally conscious mindset". Amyx, Dejong, Lin, Chakraborty and Weiner (1994) found that subjective environmental knowledge was a better predictor of ecological purchasing intentions than objective knowledge. In other words, consumers who knew more about the environment are more likely to buy environmentally friendly products than those that actually knew about environmental issues". Tilikidou and Delistavrou (2008) concluded that citizens who more frequently adopt to pro- environmental non-purchasing behaviors are all highly educated people. An ecological opinion survey on the Canadian population and a phone study of 387 municipal Atlanta inhabitants both showed that perceived knowledge seems to participate to perceived customer efficiency (Darnall, 2003). Another research has been done toward Green buying behavior of university students in Taiwan between American and Chinese customers to examine the "Theory of Planned Behavior" and for measurement of Attitudes. The result has shown that the 'Ecological Influence' has a superior impression on their attitude creation than 'Ecological Knowledge'. To realize if it can be true for Taiwanese customers, a sample of university students ( $n=41$ ) had been surveyed to evaluate their ecological impact, ecological knowledge and attitudes according green acquisitions. Although the evaluation technique used in this research varies from the full 'Theory of Planned Behavior Model', the outcomes are reliable with the findings in the earlier researches. Students with high environmental influence presented a statistically important change on their attitudes according to green acquisitions score than the students with low environmental affect. Ecological knowledge level would not prove a significant change in attitudes to green acquisitions (Shao, Lye \& Rundle, 2009). Empirical support for the impact of environmental knowledge of consumers on their satisfactory ecologically behavior is contradictory. "On one hand, it has been reported that there is no significant linkage between environmental knowledge and ecologically compatible behavior. On the other hand, it has shown that knowledge about ecological issues is a significant predictor of environmentally friendly behavior and even it has found that individuals who are highly knowledgeable about environmental issues were more willing to pay a premium price for green products" (Laroche et al., 2001). According to the above discussion the hypothesis for this section is:

H5: Consumers knowledge about the environmental issues is a motivational factor for buying environmentally friendly products. 


\subsubsection{Perceived Consumer Effectiveness}

Perceived consumer effectiveness is referred to the extent to what individuals believe that their action help for solving a problem (Weiner \& Cobb, 1991). It is defined as the self-evaluation in the context of the issue (Berger \& Corbin, 1992). Weiner and Cobb (1991) demonstrate that perceived consumer effectiveness for environmental issues is distinct from environmental concerns or attitudes and contributes to the prediction of environmentally conscious behaviors. Berger and Corbin (1992) indicated that green consumers' behavior could be influenced by their consumer perceived effectiveness (i.e., attitude) towards the protection of the environment. They argued that consumers must feel that, when they purchase an environmentally friendly product, they will make some sort of material difference. Consumer concerns about environmental issues may not always transform into pro-environmental behaviors; however, those individuals with a strong belief that their behavior will result in a positive outcome are likely to engage in such behaviors in support of their concerns for their environment (Kim \& Choi, 2005). Pickett-Baker and Ozaki (2008) claimed that "if consumer groups have pro-environmental attitudes, they may have self-concepts of themselves as environmentally responsible. Buying brands manufactured by companies whose products and processes are more environmentally friendly, enhances a desired self-concept allowing consumers to feel good about it". Perceived consumer effectiveness impacts knowledge, direct experience and the experiences of others (Kim \& Choi, 2005). An ecological opinion survey of the Canadian population and a phone study of 387 municipal Atlanta inhabitants both showed that perceived knowledge seems to participate to perceived customer effectiveness (Darnall, 2003). Majlath (2010) in an empirical study showed a statistically significant result which found that green consumers do feel that they can contribute not only to the formation of environmental problems but to the solution of them with their own actions. Following hypothesis will examines the idea of perceived consumer effectiveness.

H6: Perceived Consumer effectiveness is a factor for motivating customer to buy environmentally friendly products.

\section{Research Methodology}

The survey instrument used in this research for data collection consists a set of questionnaire. The questionnaire uses a five point Likert scale ( $1=$ strongly disagree, $5=$ strongly agree) which is divided to three parts:

- Part one: Some basic information is given to respondent about the philosophy of the research and objectives and purpose of the study. 
The first part of questionnaire is giving some basic idea about the research and what is the purpose of this research and also the main objective of this research. The information helps to inform the respondent about the main idea behind this research and about the different factors in relation to purchasing a green product.

- Part two: Demographical information (age, income and gender).

- Part three: A set of questions about the motivators for buying green products.(selfdesigned based on literature review and experts opinion).

In accordance with the different methods of sampling and considering the two main elements (characteristics of population and objectives of this study), the researchers has decided to choose the stratified sampling technique for data collection. The population for this study is the total number of international postgraduate students in all the faculties in the university. Students from different faculties will form the subgroups of the stratified sampling. The sampling size will be determined based on the Krejcie and Morgan (1970) sampling method. There are 21 faculties with 8542 students in UTM (Universiti Teknologi Malaysia) Therefore the sample size of 367 students were selected for distributing the questionnaire.

To analyze the data which was collected through the questionnaire, factor analysis and sample $T$ test has been used. Statistical Program for Social Sciences (SPSS) has been used as the data analysis tool. The aim of the data analysis was finding the main motivators that impact costumer decision making process.

\section{Identification of Green Purchasing Motivators' Constructs Using Factor Analysis}

As mentioned in the literature, conducting an exploratory factor analysis is necessary to insure the validity of items. For this reason the factor analysis was conducted with the eigenvalue $(1 \leq)$ and rotated component matrix.

The results of factor analysis are discussed as below:

The first factor is divided into three factors. The variables related to first factor, which consists of three mentioned factors are shown in the following list.

- I am encouraged to purchase products that are environmental friendly because I am informed about environment pollutions.

- I am encouraged to buy green products because I have knowledge about recyclable products and degradable products. 
- I am motivated to buy environmental friendly products because I have knowledge about global warming.

- Environmental concern motivates me to buy environmental friendly products because I am concern for environment.

- I am motivated to buy Environmental friendly products because I want to protect the environment.

- I am encouraged to purchase environmental friendly products that are harmless to the environment.

- Environmental concern motivates me to buy environmental friendly products because I am concern for environment.

- I am motivated to buy Environmental friendly products because I want to protect the environment.

- I am encouraged to purchase environmental friendly products that are harmless to the environment.

The next component is promotional tools (second factor). Its variables showed the highest eigenvalue among the components (located in the second column in this matrix). The items are as shown below:

- I am encouraged to buy environmental friendly products because of the on line advertisement concerning environmental friendly products.

- I am encouraged to buy environmental friendly products because I am convinced by the television and radio advertisement.

- I am encouraged to buy environmental friendly products because of the billboard advertisement that encourages me to buy environmental friendly products.

The third part is the three Laws and regulation's variables, as the next underlying factors which are listed down.

- I am motivated to buy green products of the obligation imposed by the government concerning environmental conservation.

- I do not want to disobey the environmental laws and regulation; thus I am encouraged to purchase products that are not harmful for the environment.

- I am motivated to purchase green products because I am aware of the existing environmental laws and regulations. 
Lastly the forth factor in this matrix are:

- I am a member of an organization which advocates caring, protecting and saving the environment, thus I am motivated to purchase environmental friendly products.

- I buy green products I am influenced by my coworkers.

- I am influenced by my friends and my family to purchase environmental friendly products.

The four factors are underlying factors:

Consumer's concern, perceived effectiveness and knowledge (the researchers did not change the name of these underlying factors and used a composed name with respect to other researchers' findings) have been merged through the factor analysis. Six factors as mentioned in the literature review are reduced to four underlying factors regarding their characteristics and respondents opinion in this study. Consequently, in line with the second objective, a new construct with four underlying factors has been identified as follows:

- Consumer's concern, Perceived effectiveness and Knowledge.

- Promotional tools.

- Laws and regulations.

- Reference group.

\section{Reliability and Validity Test}

\subsection{Reliability}

As a basis for every statistical analysis, it is important to calculate reliability of items. For such a reason using the SPSS reliability analysis program, an internal consistency analysis were performed for all of items and the Cronbach's Alpha obtained is $0.893(>0.80)$. Clark and Watson (1995) noted, the issue of internal consistency reliability assessment is complicated by the fact that "there are no longer any clear standards regarding what level is considered acceptable" for Cronbach's alpha (p. 315); past criteria have ranged from .80 or .90 alpha coefficients, down to .60 or .70 alphas. So based on this definition and according to Cronbach's Alpha which is .893 these variable are reliable and can be used for analytical purposes. 


\subsection{Validity}

In dealing with the content validity, the authors used three approaches:

- Selection of the measurement items was based on comprehensive review of literature. In this study, researchers extensively reviewed of international journals (in the field of consumer behavior and marketing).

- Soliciting input and feedback from the experts (Cooper \& Schindler, 2000; Nunnally \& Bernstein, 1994) to improve the instrument. Accordingly several interviews been conducted with three expert professors with vast knowledge in the field of marketing and social sciences consulting with other PhD candidates who possess knowledge for designing questionnaire.

- 37 sets of questionnaires were distributed among the postgraduate students.

\begin{tabular}{|c|c|c|c|c|c|}
\cline { 2 - 5 } \multicolumn{1}{l|}{ Name of faculty } & $\begin{array}{c}\text { Morgan } \\
\text { sample size }\end{array}$ & Rounded & $\begin{array}{c}\text { Amount for } \\
\text { validity and } \\
\text { reliability }\end{array}$ & Rounded \\
\hline $\mathbf{1}$ & Faculty of Built Environment (FAB) & 19.1 & 19 & 1.9 & 2 \\
\hline $\mathbf{2}$ & $\begin{array}{l}\text { Faculty of Biosciences and } \\
\text { Bioengineering (FBB) }\end{array}$ & 8.6 & 9 & 1.9 & 2 \\
\hline $\mathbf{3}$ & Faculty of Civil Engineering (FKA) & 31.6 & 32 & 3.2 & 3 \\
\hline $\mathbf{4}$ & $\begin{array}{l}\text { Faculty of Biomedical Engineering and } \\
\text { Health Science (FKBSK) }\end{array}$ & 3.4 & 3 & 0.3 & - \\
\hline $\mathbf{5}$ & $\begin{array}{l}\text { Faculty of Computer Science and } \\
\text { Information System (FSKSM) }\end{array}$ & 37.8 & 38 & 3.8 & 4 \\
\hline $\mathbf{6}$ & Faculty of Electrical Engineering (FKE) & 35.1 & 35 & 3.5 & 4 \\
\hline $\mathbf{7}$ & FGHT & 14.1 & 14 & 1.4 & 1 \\
\hline $\mathbf{8}$ & $\begin{array}{l}\text { Faculty of Mechanical Engineering } \\
\text { (FKM) }\end{array}$ & 28.3 & 28 & 2.8 & 3 \\
\hline $\mathbf{9}$ & FKKKSA & 0.17 & 0 & 0 & - \\
\hline $\mathbf{1 0}$ & Faculty of Education (FP) & 65.4 & 64 & 6.4 & 6 \\
\hline $\mathbf{1 1}$ & $\begin{array}{l}\text { Faculty of Management and Human } \\
\text { Resource Development (FPPSM) }\end{array}$ & 28.1 & 28 & 2.8 & 3 \\
\hline $\mathbf{1 2}$ & Faculty of Science (FS) & 33.5 & 34 & 3.4 & 3 \\
\hline $\mathbf{1 3}$ & FKK & 20.7 & 21 & 2.1 & 2 \\
\hline $\mathbf{1 4}$ & $\begin{array}{l}\text { Faculty of Petroleum and Renewable } \\
\text { Energy Engineering (FPREE) }\end{array}$ & 4.7 & 5 & 0.5 & 1 \\
\hline $\mathbf{1 5}$ & FTI & 2.9 & 3 & 0.3 & - \\
\hline $\mathbf{1 6}$ & IBS & 16.1 & 16 & 1.6 & 2 \\
\hline $\mathbf{1 7}$ & MJIIT & 1.1 & 1 & 0.1 & - \\
\hline $\mathbf{1 8}$ & SPS & 4.68 & 5 & 0.5 & - \\
\hline $\mathbf{1 9}$ & UTM AIS & 1.1 & 1 & 0.1 & - \\
\hline $\mathbf{2 0}$ & UTM Perdan & 8,3 & 8 & 0.8 & 1 \\
\hline $\mathbf{2 1}$ & UTM Razak & & $\mathbf{3 6 7}$ & 36.7 & 37 \\
\hline & Total & & & \\
\hline
\end{tabular}

Table 1 . Sample size and pilot test population according to faculties information 
A pilot test was done among the respondents (10\% of sample size) for validity. Table 1 shows sample size and pilot test population of this survey. The first column explains the number of selected students in each faculty which is calculated based on Morgan Sample. The second column is the rounded number. The forth column is the number of selected student for pilot test which is $10 \%$ of total student in that specific faculty. The last column is the rounded number which serves as a total number of students which was given the questionnaire.

\subsection{Construct Validity}

Dimensions of "Green Motivators" and percentage value of variance are $67.96 \%$. In a social science research, the rule of thumb for this criterion is that a factor solution should account for a minimum of 60 percent of total variance (Hair, Babin, Money \& Samouel, 2003).

\section{Most Important Factors According to T Test}

In literature review, 6 factors have been discussed. Finally for validating the construct consist of these six factors, a factor analysis was conducted and a new construct with four variables are determined. Subsequently for understanding that which one of these four underlying factors are the most important motivator to motivate the customers for buying green products one- sample $T$ test has been conducted. For such a reason, the following procedure should be considered.

Compute the variables mean for each variable

Conditions:

$$
\begin{aligned}
& \text { Test value }=3 \\
& \mathrm{H} 0=M \leq 3 \\
& \mathrm{H} 1=M>3 \\
& P \text { value divided by } 2
\end{aligned}
$$

95\% Confidence Interval of the Difference

A one sample $T$ test was conducted which is shown in Table 2.

The result shows that promotional tools has a mean score of 3.3573 which is significantly more than test value and then a standard deviation of 0.94811 and a $P$ value of zero. So based on 
these statistical information, it is obvious that the promotional tools are really important motivators for buying the green products.

For the reference group, the mean is 2.9271 which is less than 3 and $P$ value is 0.000 . These results show that Reference Group is not significant in motivating the customer for buying environmentally friendly products.

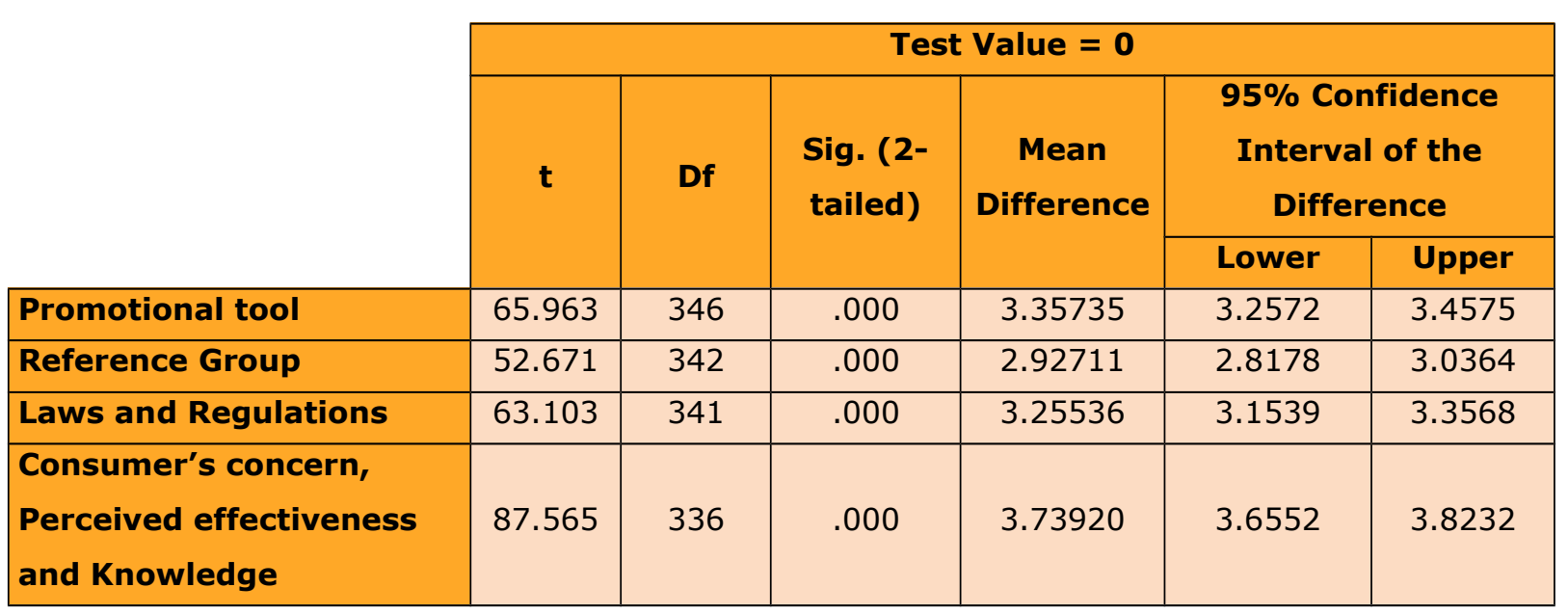

Table 2. One-Sample T Test

Laws and regulation is the next item which is examined by one sample $T$ test. The result shows 3.2554 as the mean, 0.95402 as standard deviation and $P$ value of zero. The significant difference between laws and regulation's mean number and test value's number, the $P$ value and other statistical information, indicate that the rules and regulations are motivating factors that affect the costumer decision making process.

The last factor which is Consumer's concern, Perceived effectiveness and Knowledge. Statistical information (mean $=3.7392$ and $P$ value $=0.00$ ) prove that this underlying factor is the most important motivators for buying environmentally friendly products.

\section{Discussion and Conclusion}

In reference to the result, the first objective of this research (to investigate the common important motivators for buying the green products) has been achieved through reviewing the literatures and determination of 6 main motivators from different authors.

A factor analysis has been conducted for building and validating construct for underlying factors or general motivators for buying green products. By using factor analysis eighteen 
underlying factors which are divided to four main factors (dimensions) and dimensions has been shaped.

Finally regarding the last objective of this research, a sample $T$ test has been conducted to find out which factors is important in impacting and motivating consumers to buying green products. The result of second objective is discussed in subsequent paragraphs.

- Promotional Tools: In this survey, the people expressed that they are affected by promotional tools like radio and TV. Normally the media have a strong ability to persuade the people in buying the environmentally friendly products and make them aware of natural issues and climate change problems. This is the reason that people determined this factor as an important factor or motivator for buying environmentally friendly products. By considering the important of promotional tools, companies can use it as a strategic key factor for persuading their customers for buying ecologically friendly products.

- Consumer Knowledge, Perceived effectiveness and Concern is also one of the important factors for buying environmentally friendly products since the population of this survey had enough knowledge about the products degradability concept and recyclability. This isto decrease the waste of resources and pollution. Moreover the majority of them, based on academic background, expressed that the consumer knowledge, perceived effectiveness and concern is an underlying motivator and can be one of most important motivators for buying green products. Furthermore authorities and companies can increase the consumer green purchasing intention by increasing their concern about the scarcity in resources and global warming. They should let them know the how importance for solving environmental issues through buying and using environmentally friendly products and services. Increasing the customers/consumers knowledge and level of eco-literacy can positively influence their green buying behavior as well.

- Laws and Regulation: based on respondent's suggestions, rules and regulations is determined as a significant factor for buying environmentally friendly products. Respondents agreed that rules and regulation has a significant effect on their decisions while some of them believed that still there is no obligatory rules and regulation in some of the world's countries that disallow consumer for using non-environmental friendly products. It shows that law and regulation endorsed by authorities can play a significant role for shaping the peoples' attitude in the usage of environmentally friendly products.

- Reference Group: The reference group has been defined as an underlying factor for buying environmentally friendly product. However after conducting the one sample Ttest, the results indicate that the reference group is a motivator for buying 
environmentally friendly products. Respondent said that they usually follow their friends for buying environmentally friendly products. The majority of them believe that their organizations' co-workers and other groups have no impact on them for buying environmentally friendly products. Therefore reference group is not identified as a motivational factor. In contradiction with previous researchers 'result and while the reference group isone of component of subjective norms in the of Theory of Planned Behavior (Anvari, Irum, Ashfaq \& Atiyaye, 2014; Ajzen, 1985) the respondents believe that reference group has no influence on their green purchasing behavior.

As a result this research was able to identify the most important motivators of buying green products, the producers whereas environmental communities and governments can use the promotional tools (Media such as radio, magazines, billboards and TV, etc.) in order to persuade the consumers for purchasing green products. Furthermore NGOs and governments should be aware that improving the society's knowledge and grabbing people's attention to the importance of environmental issues and making them concern about the climate change, could help to solve the environmental issues. If consumers think that they have a significant role by purchasing green products, this perception will affect their purchasing behavior. The authorities could use any tool to improve the knowledge and motivate the consumers in this way. Respondents also stressed on the role of rule makers (countries parliaments and governments) in legislation toward respecting the environment for producing and using green products. The main contribution of this research is in finding the key factors that can impact consumer's decision making process by motivating them to buy green products which finally lead to overcome on environmental issues. Furthermore as the consumers are the main target of producers and retailers for selling the products and gaining profit, changing the consumer's perspective from using non-environmental friendly products to environmental friendly products will force the manufacturers to shift to producing the environmental friendly products which, can help to improve the quality of environment. This helps reducing the negative side effects of industrial process and also manufacturers' contribution to solve the environmental problems.

\section{Contribution, Consideration, Limitations and Future Work}

This paper aims to investigate the most important factors that motivate consumers to buy green products. By understanding those factors companies can persuade their customers to buy green products which in turn will help to improve the quality of environment.

Since this research is a quantitative research, so objective of this study is achieved by reviewing the past literature and factors those influence customers to purchase green products. Then hypothesis have been built and factor analysis conducted to evaluate the 
construct then sample $T$ used to find the important factors. The scope of research includes potential buyers which in this case students from university have been chosen as respondents. Results show that Environmental Concern, Perceived Consumer Effectiveness, Consumer Knowledge, Laws and regulation and Promotional Tools' were the most important of motivators.

- Practical implication: This study can help companies, authorities, governments, producers, sellers and all of the parties those want to participate in solving environmental issues. Producers can use these green motivators for encouraging the consumers for choosing green products.

- Academic implication: This study tries to fill the gap regarding what really influence consumers' motivation for buying green products by gathering motivators of buying green products. By doing so the contribution of this study is adding new knowledge to consumer behavior and also marketing and green marketing.

- Social implication: This research will indirectly contribute to peoples' understanding, knowledge, and attitude for going green and take their part in solving environmental issues and make less environmental side effect. It is notable that motivated consumers for buying green product will finally contribute for having a healthy life and clean environment.

- Consideration and future work: Despite these motivators, people may also be influenced by some or all of these motivators in different levels. These dimensions also can be used by different authors for to study whether how people in different geographical area and with different attitude are influenced by which one of these dimensions and could influence their purchasing decision in an environmentally friendly way. This study also can be done among different age groups and ethnicity groups in Malaysia.

- Limitations: Due to the idea of respondents and conducting a factor analysis a miss match happened between the number of dimension before conducting the factor analysis and after factor analysis. Hence the authors merged the three dimensions (consumer's concern, perceived effectiveness and knowledge) and try to keep the name of all dimensions as they believed they can be used separately and also under a unique dimension based on the idea of researchers in future works. 


\section{References}

AJZEN, I. (1985). From intentions to actions: A theory of planned behavior. In J. Kuhl \& J. Beckman (Eds.), Action-control: From cognition to behavior (pp. 11-39). Heidelberg: Springer. http://dx.doi.org/10.1007/978-3-642-69746-3_2

AMYX, D.A.; DEJONG, P.F.; LIN, X.; CHAKRABORTY, G.; WEINER, J.L. (1994). Influencers of purchase intentions for ecologically safe products: an exploratory study. In Park, C.W. et al. (Eds.), AMA Winter Educators' Conference Proceedings. American Marketing Association, Chicago. IL, 5 (pp. 341-347).

ANVARI, R.; IRUM, S.; ASHFAQ, M.; ATIYAYE, D.M. (2014). The impact of leader's cultural intelligence on organizational commitment. Asian Social Science, 10(17): 45-51. http://dx.doi.org/10.5539/ass.v10n17p45

BELZ, F.-M.; PEATTIE, K. (2009). Sustainability Marketing. A global perspective (1st Ed.). Glasgow: John Wiley \& Sons.

BERGER, I.; CORBIN, R.M. (1992). Perceived Consumer Effectiveness in faith in others as moderators of environmentally responsible behaviours. Journal of Public Policy and Marketing, 3(11): 79-89.

BERGERON, J.; LAROCHE, M.; BARBARO FORLEO, G. (2001). Targeting consumers who are willing to pay more for environmentally friendly products. Journal of Consumer Marketing, 18(6): 503-521. http://dx.doi.org/10.1108/EUM0000000006155

BOHLEN, G.; SCHLEGELMILCH, B.B.; DIAMANTOPOULOS, A. (1993). Measuring Ecological Concern: A Multi-Construct Perspective. Journal of Marketing Management, 9: 415-430. http://dx.doi.org/10.1080/0267257X.1993.9964250

BOZTEPE, A. (2012). Green Marketing and Its Impact on Consumer Buying Behavior. European Journal of Economic and Political Studies, 5(1): 5-21.

CHARTER, M.; PEATTIE, D.; OTTMAN, J.; POLONSKY, M.J. (2002). Marketing and Sustainability. The Centre for Business Relationships, Accountability, Sustainability and Society (BRASS), UK, Cardiff: Brass.

CLARK, L.A.; WATSON, D. (1995). Constructing validity: Basic issues in objective scale development. Psychological Assessment, 7: 309-319. http://dx.doi.org/10.1037/1040-3590.7.3.309

COOPER, D.R.; SCHINDLER, P.S. (2000). Bussiness research model (7th ed.). New York: McGraw-Hill/Irwin.

DARNALL, N. (2003). Why Consumers Buy Green. Journal of Public Policy, 10: 1-3.

DAVIS, J.J. (1992). Ethics and Environmental Marketing. Journal of Business Ethics, 11: 81-87. http://dx.doi.org/10.1007/BF00872314 
DAVIS, J.J. (1994). Consumer Response to Corporate Environmental Advertising. Journal of Consumer Marketing, 11(2): 25-37. http://dx.doi.org/10.1108/07363769410058902

DRIESEN, D. (2007). The Changing Climate for United States Law. Carbon and Climate Law Review, 1: 35-44.

ENGEL, J.F.; BLACKWELL, R.D.; MINIARD, P.W. (1995). Consumer behavior. International edition. Florida: The Dryden press.

FRANKEL, C. (1992). Blueprint for Green Marketing. American Demographics, April: 34-38.

GILLESPIE, R.J. (1992). Pitfalls and Opportunities for Environmental Marketers. Journal of Business Strategy, July/August: 14-17. http://dx.doi.org/10.1108/eb039500

GRANT, A.M.; BERRY, J.W. (2011). The Necessity of Others is The Mother of Invention: Intrinsic and Prosocial Motivations, Perspective Taking, and Creativity. Acad Manage, 54(1): 73-96. http://dx.doi.org/10.5465/AMJ.2011.59215085

HAIR, J.F. JR; BABIN, B.; MONEY, A.T.; SAMOUEL, P. (2003). Essential of business research methods. New Jersey: John Willy and Son, Inc.

HALLIN, P.O. (1995). Environmental concern and environmental behaviour in Foley, a small town in Minnesota. Environment and Behaviour, 27(4): 558-578.

http://dx.doi.org/10.1177/0013916595274006

HAYES, D. (1990). The green decade. The Amicus Journal, 12: 24-29.

HOYER, W.D.; MACINNIS, D.J. (2007). Consumer Behavior (4th Edition). Boston: Houghton Mifflin.

HUEBER, G. (1991). Americans report high levels of environmental concern. Gallup Poll Monthly, 307: 6-12.

HUME, S. (1991). Consumer double talk makes companies wary. Advertising Age, 62(46): 6264.

KACEN, J.J.; LEE, J.A. (2002). The Influence of Culture on Consumer Impulsive Buying Behavior. Journal of consumer psychology, 12(2): 163-176.

http://dx.doi.org/10.1207/S15327663JCP1202_08

KIM, Y.; CHOI, S.M. (2005). Antecedents of Green Purchase Behaviour: An Examination of Collectivism, Environmental Concern and PCE. Advances in Consumer Research, 32: 592-597.

LAROCHE, M.; BERGERON, J.; BARBARO-FORLEO, G. (2001). Targeting consumers who are willing to pay more for environmentally friendly products. Journal of Consumer Marketing, 18(6): 503-520. http://dx.doi.org/10.1108/EUM0000000006155 
MAJLATH, M. (2010). Can Individuals do anything for the Environment? The Role of Perceived Consumer Effectiveness. Proceedings of FIKUSZ, 10: 157-166.

MASLOW, A.H. (1943). A Theory of Human Motivation. Psychological Review, 50: 370-396. http://dx.doi.org/10.1037/h0054346

MCCARTY, J.A.; SHRUM, L.J. (2001). The influence of individualism, collectivism and locus of control on environmental beliefs and behavior. Journal of Public Policy and Marketing, 20(1): 93-104. http://dx.doi.org/10.1509/jppm.20.1.93.17291

MENDLESON, N.; POLONSKY, M.J. (1994). Using strategic alliances to develop credible green marketing. Journal of Consumer Marketing,12(2): 4-18.

http://dx.doi.org/10.1108/07363769510084867

NUNNALlY, J.C.; BERNSTIEN, I.H. (1994). Psychometric theory (3rd ed.). New York: McGrawHill, Inc.

OTTMAN, J. (1992). Industry's Response to Green Consumerism. Journal of Business Strategy, July/August: 3-7. http://dx.doi.org/10.1108/eb039498

PAÇO, A. DO; RAPOSO, M. (2009). "Green" segmentation: an application to the Portuguese consumer market. Marketing Intelligence \& Planning, 27(3): 364-379.

http://dx.doi.org/10.1108/02634500910955245

PHILLIPS, L.E. (1999). Green Attitude. American Demographics, 21(4): 46-47.

PICKETT-BAKER J.; OZAKI, R. (2008). Pro-environmental products: marketing influence on consumer purchase decision. Journal of Consumer Marketing, 25: 281-293. http://dx.doi.org/10.1108/07363760810890516

PROTHERO V.; TURNER, W.; STONEMAN, P. (1997). Marketing strategies and market prospects for environmentally-friendly consumer products. British Journal of Management, 7(3): 263-281.

RAO, A.; CHILDERS, T.L. (1992). The Influence of Familial and Peer Based Reference Group Influence on Consumer Decisions. Journal of Consumer Marketing, 19: 198-211.

ROBERTS, J.A.; BACON, D.R. (1997). Exploring the subtle relationship between environmental Concern and ecologically conscious consumer behavior. Journal of Business Research, 40(1): 79-89. http://dx.doi.org/10.1016/S0148-2963(96)00280-9

SANDHUSEN, R.L. (2000). Marketing, Barron's Business Review Series (3rd edition). New York, NY: Barron's educational Series.

SCHIFFMAN, L.G.; KANUK, L.L. (2007). Consumer Behavior (9th edition). Upper Saddle River, N.J.: Pearson Prentice Hall, London. 
SCHLOSSBERG, H. (1992). Marketers Warned to Heed Message of 'Ecologism'. Marketing News, March 30: 6.

SHAO, W.; LYE, A.; RUNDLE, T.S. (2009). Different strokes for different folks: A method to accommodate decision -making heterogeneity. Journal of Retailing and Consumer Services, 16(6): 495-501. Elsevier. http://dx.doi.org/10.1016/j.jretconser.2009.08.004

TALLURI, S. (2002). A buyer - seller game model for selection and negotiation of purchasing bids. European Journal of Operational Research, 143: 171-180. http://dx.doi.org/10.1016/S03772217(01)00333-2

TILIKIDOU, I.; DELISTAVROU, A. (2008). Types and influential factors of consumers' nonpurchasing ecological behaviors. Business Strategy and the Environment, 17(1): 61-76. http://dx.doi.org/10.1002/bse.500

WAGNER, A.S. (1997). Understanding Green Consumer Behaviour: A Qualitative Cognitive Approach (304). New York: Routledge.

WEINER, E.; COBB, W. (1991). The role of Perceived Consumer Effectiveness in Motivating Environmentally Conscious Behaviours. Journal of Public Policy and Marketing, 3(10): 102-117.

WHEELER, W.A. III (1992). The Revival in Reverse Manufacturing. Journal of Business Strategy, July/August: 8-13.

YAM-TANG, E.P.Y.; CHAN, R.Y.K. (1998). Purchasing behaviours and perceptions of environmentally harmful products. Marketing Intelligence \& Planning, 16(6): 356-362. http://dx.doi.org/10.1108/02634509810237532

YEONSHIN, K.; SEJUNG, M.C. (2005). Antecedents of Green Purchase Behavior: An Examination of Collectivism, Environmental Concern, and PCE. Advances in Consumer Research, 32: 592-599.

ZINKHAN, G.M.; LES, C. (1995). Green Advertising and the Reluctant Consumer. Journal of Advertising, Summer: 16.

ZIMMER, M.R.; STAFFORD, T.F.; STAFFORD, M.R. (1994). Green Issues: Dimensions of Environmental Concern. Journal of Business Research, 31(1): 63-74.

http://dx.doi.org/10.1016/0148-2963(94)90069-8

Intangible Capital, 2014 (www.intangiblecapital.org)

\section{(a)}

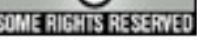

Article's contents are provided on a Attribution-Non Commercial 3.0 Creative commons license. Readers are allowed to copy, distribute and communicate article's contents, provided the author's and Intangible Capital's names are included. It must not be used for commercial purposes. To see the complete license contents, please visit http://creativecommons.org/licenses/by-nc/3.0/. 